\title{
Fusarium Infection
}

\section{Report of 26 Cases and Review of 97 Cases From the Literature}

\author{
Maged Muhammed, MD, * Theodora Anagnostou, MD, * Athanasios Desalermos, MD, \\ Themistoklis K. Kourkoumpetis, MD, Herman A. Carneiro, MBBS, MSc, Justin Glavis-Bloom, BA, \\ Jeffrey J. Coleman, PhD, and Eleftherios Mylonakis, MD, PhD
}

\begin{abstract}
Fusarium species is a ubiquitous fungus that causes opportunistic infections. We present 26 cases of invasive fusariosis categorized according to the European Organization for Research and Treatment of Cancer/Mycoses Study Group (EORTC/MSG) criteria of fungal infections. All cases ( 20 proven and 6 probable) were treated from January 2000 until January 2010. We also review 97 cases reported since 2000. The most important risk factors for invasive fusariosis in our patients were compromised immune system, specifically lung transplantation $(n=6)$ and hematologic malignancies $(\mathrm{n}=5)$, and burns $(\mathrm{n}=7$ patients with skin fusariosis), while the most commonly infected site was the skin in 11 of 26 patients. The mortality rates among our patients with disseminated, skin, and pulmonary fusariosis were $50 \%, 40 \%$, and $37.5 \%$, respectively. Fusarium solani was the most frequent species, isolated from $49 \%$ of literature cases. Blood cultures were positive in $82 \%$ of both current study and literature patients with disseminated fusariosis, while the remaining $16 \%$ had 2 noncontiguous sites of infection but negative blood cultures. Surgical removal of focal lesions was effective in both current study and literature cases.

Skin lesions in immunocompromised patients should raise the suspicion for skin or disseminated fusariosis. The combination of medical monotherapy with voriconazole or amphotericin B and surgery in such cases is highly suggested.
\end{abstract}

(Medicine 2013;92: 305-316)

Abbreviations: COPD = chronic obstructive pulmonary disease, EORTC $=$ European Organization for Research and Treatment of Cancer, $\mathrm{FSSC}=$ Fusarium solani species complex, G-CSF = granulocyte colony-stimulating factor, GM-CSF = granulocyte macrophage colony-stimulating factor, HSCT $=$ hematopoietic stem cell transplant, IFICG = Invasive Fungal Infection Cooperative Group, MIC = minimum inhibitory concentration, MSG $=$ Mycoses Study Group, MGH $=$ Massachusetts General Hospital, NIAID = National Institute of Allergy and Infectious Diseases.
From the Division of Infectious Diseases (MM, TA, AD, TKK, HAC, JG-B, JJC, EM), Harvard Medical School, Massachusetts General Hospital, Boston, Massachusetts; and Division of Infectious Diseases (TA, JJC, EM), Warren Alpert Medical School of Brown University, Rhode Island Hospital, Providence, Rhode Island.

*These authors contributed equally to the study.

Financial support and conflicts of interest: This research was supported by a National Institutes of Health grant P01 AI 083214, a R01 award AI075286 and a R21 award AI079569 to EM, and a T32 AI007061 to JJC. The authors have no conflicts of interest to disclose.

Reprints: Eleftherios Mylonakis, MD, PhD, Warren Alpert Medical School of Brown University, Rhode Island Hospital, 593 Eddy Street, Providence, RI 02903 (e-mail: emylonakis@lifespan.org).

Copyright (C) 2013 by Lippincott Williams \& Wilkins

ISSN: 0025-7974

DOI: 10.1097/MD.0000000000000008

\section{INTRODUCTION}

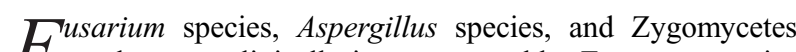
$\mathcal{H}$ are the most clinically important molds. Fusarium species isolates are universally found in the environment and cause infection in both humans and plants. ${ }^{29,35,94,95,97}$ In humans, infection starts with the inhalation of Fusarium conidia or direct contact with materials contaminated with Fusarium conidia. Subsequently, conidia germinate and form filaments that invade the surrounding tissue when a suitable environment is offered.

There is a paucity of reports describing the predisposing factors and clinical characteristics of patients with Fusarium infection. ${ }^{77}$ The clinical presentation of fusariosis depends on the host's immune status. ${ }^{140}$ Invasive infections, such as sinusitis, pneumonia, deep cutaneous infections, and disseminated infections, present in immunocompromised patients and most commonly manifest as fever not responding to antimicrobial medications. ${ }^{96}$ Specifically, neutropenia, deficits in cellular immunity, induction chemotherapy for leukemia, and hematopoietic cell transplantation are considered risk factors for the development of invasive fusariosis. ${ }^{15,96,98}$ On the other hand, immunocompetent patients present more frequently with superficial infections, such as keratitis and onychomycosis. ${ }^{19,49,50,60}$

In the current study, we describe the clinical characteristics of 26 patients with proven or probable invasive fusariosis managed at Massachusetts General Hospital (MGH) during a 10 -year period and review the literature of cases with fusariosis published since January 2000, focusing on the therapeutic approach and outcome of patients.

\section{PATIENTS AND METHODS}

We identified patients with fusariosis treated at $\mathrm{MGH}$ from January 2000 to January 2010 by searching the records of the clinical microbiology laboratory at MGH, Boston, MA. We collected data by reviewing the electronic medical records of the patients; we retrieved their baseline characteristics, underlying diseases, treatment modalities, and outcome. We categorized all patients according to the revised definitions of the European Organization for Research and Treatment of Cancer/ Invasive Fungal Infections Cooperative Group and the National Institute of Allergy and Infectious Diseases Mycoses Study Group (EORTC/IFICG and NIAID/MSG) into proven and probable cases. ${ }^{28}$ We defined disseminated fusariosis as any case with at least 1 positive blood culture or with the concurrent involvement of 2 or more noncontiguous sites. Neutropenia was defined as an absolute neutrophil count $\leq 500$ cells $/ \mu \mathrm{L}$, while steroid therapy was defined as the use of prednisone or prednisone-equivalent at a dose equal to or higher than $10 \mathrm{mg} /$ day. For simplicity, the term "skin infection" was used to describe fusariosis involving the skin with or without involvement of other soft tissues. The study was approved by the institutional review board of MGH. 


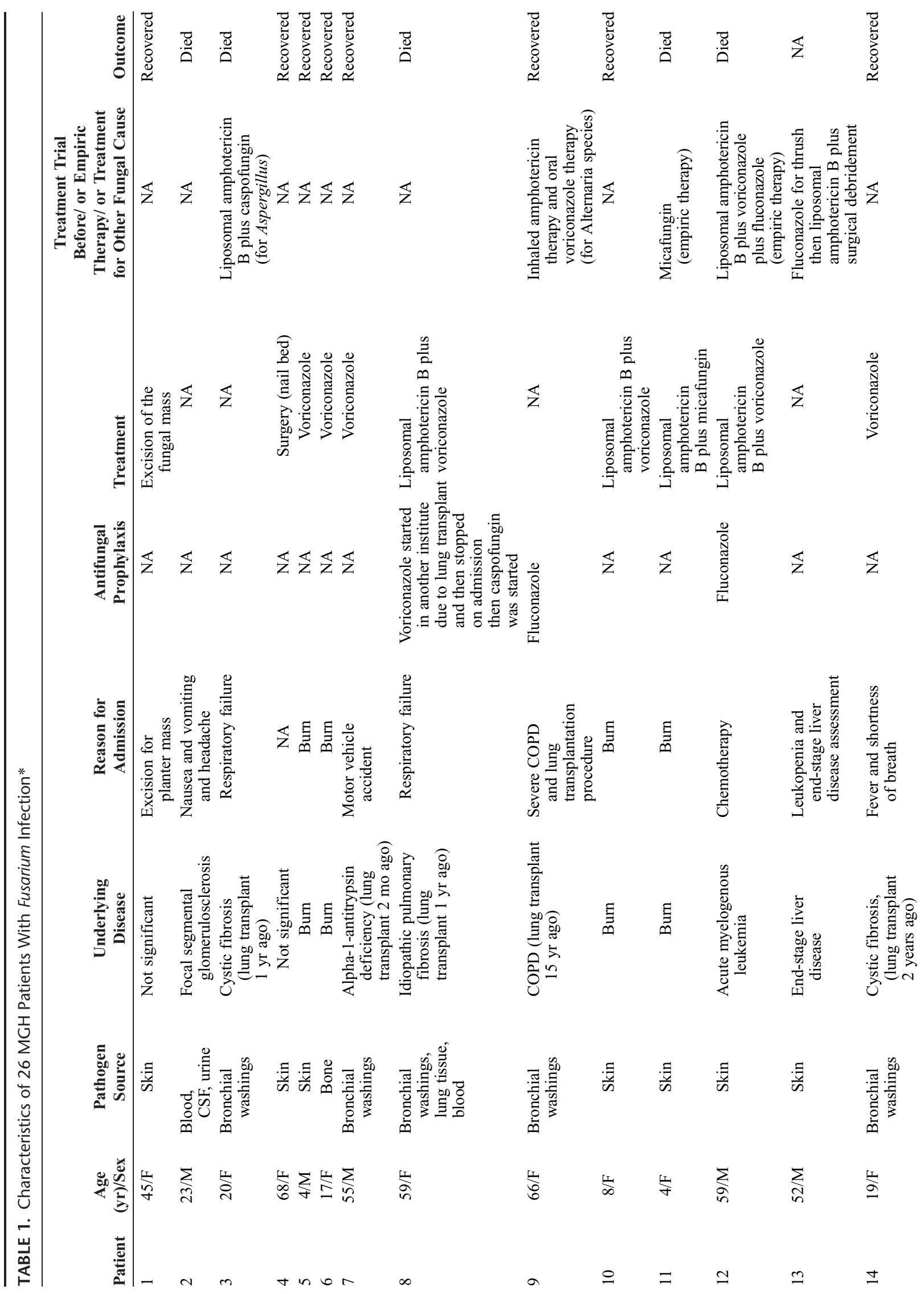




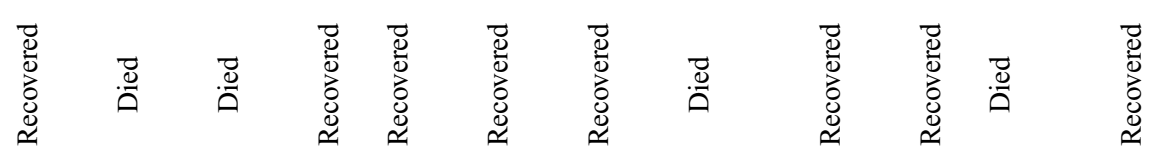

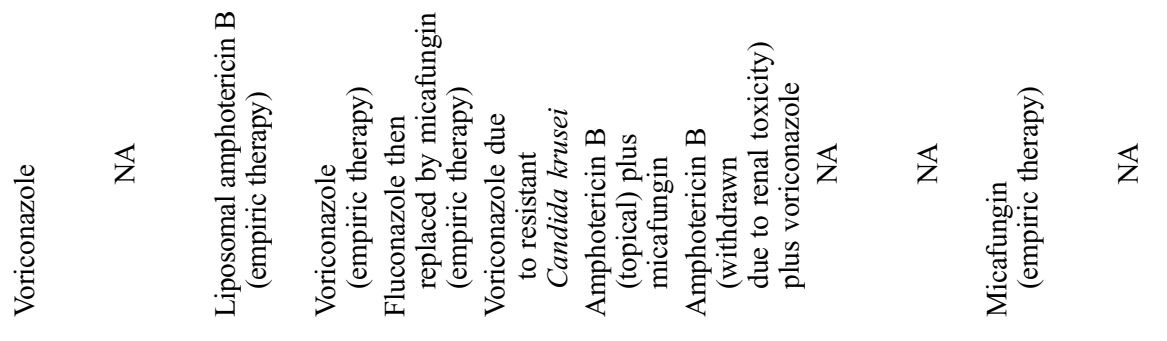

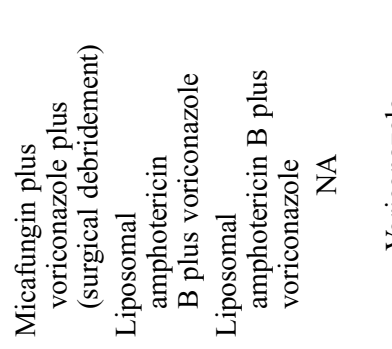

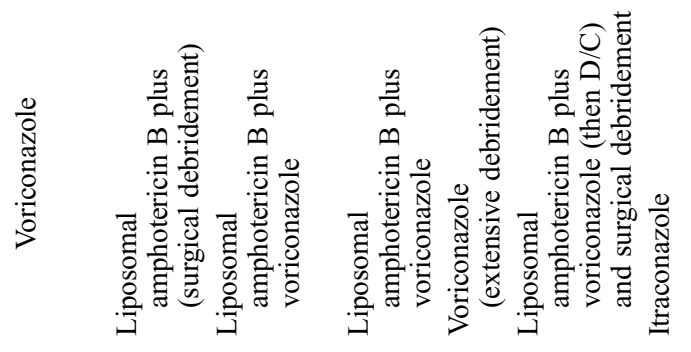

飞

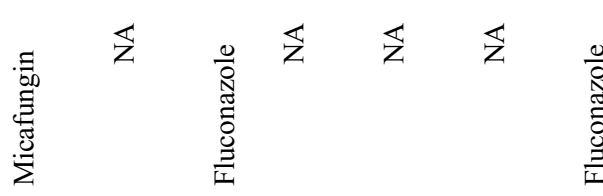<smiles>[13CH3][13CH3]</smiles>

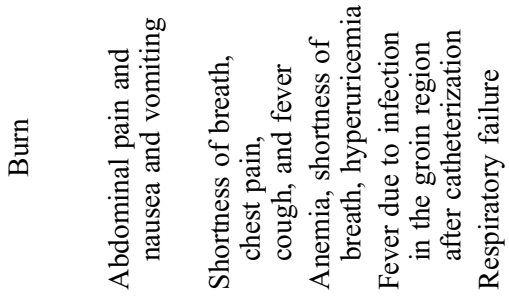

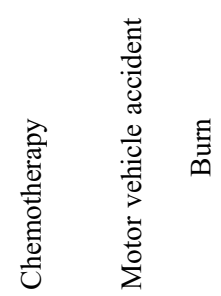

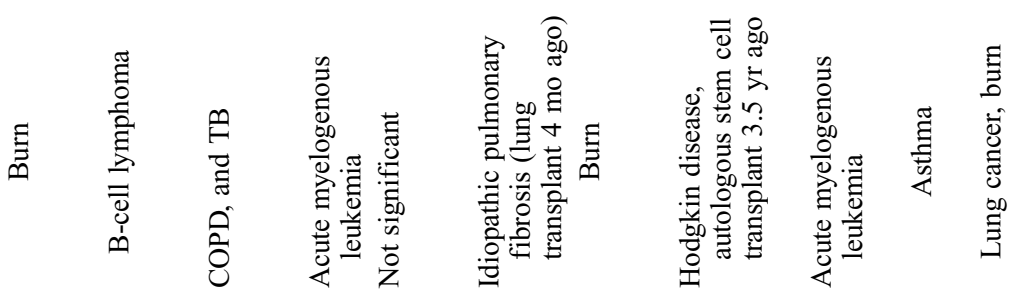

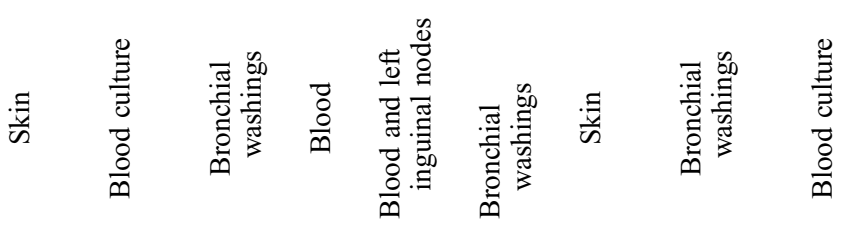

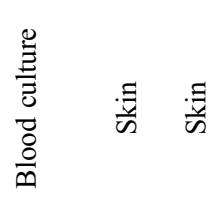

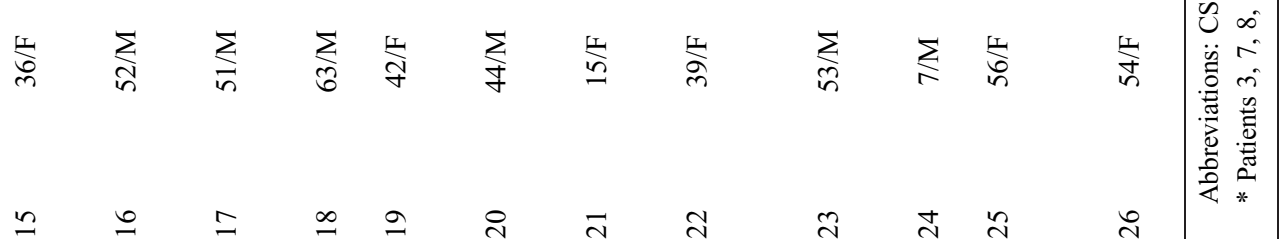


In our literature review, we identified published cases of fusariosis in the English literature by searching the MEDLINE database (National Library of Medicine, Bethesda, MD) using the terms "Fusarium" or "fusariosis." Non-English language studies, expert commentaries, and abstracts from scientific meetings were excluded. Of note, in order to focus on invasive fusariosis, we also excluded patients with superficial localized infections, such as keratitis and onychomycosis. Finally, we excluded cases with positive cultures for Fusarium species but without histopathologic confirmation, and cases with limited data.

\section{RESULTS}

\section{Case Series}

We identified 26 patients with proven $(n=20)$ or probable $(\mathrm{n}=6)$ invasive fusariosis. The mean age was 38 years (range, 4-68 yr). Table 1 represents the baseline patient characteristics. The most common underlying conditions included burns $(\mathrm{n}=7)$, lung transplantation $(\mathrm{n}=6$, performed $2 \mathrm{mo}, 4 \mathrm{mo}, 1 \mathrm{yr}, 1 \mathrm{yr}$, $2 \mathrm{yr}$, and $15 \mathrm{yr}$ before the diagnosis of fusariosis was established) and hematologic malignancies $(n=5)$, such as acute myeloid leukemia $(\mathrm{n}=3)$, B-cell lymphoma $(\mathrm{n}=1)$, and Hodgkin lymphoma treated with stem cell transplantation 3.5 years before the index hospitalization $(\mathrm{n}=1)$. Less frequent underlying diseases included focal segmental glomerulosclerosis $(n=1)$, end-stage liver disease $(\mathrm{n}=1)$, chronic obstructive pulmonary disease (COPD) and tuberculosis $(\mathrm{n}=1)$, lung cancer and $\operatorname{COPD}(\mathrm{n}=1)$, and asthma $(\mathrm{n}=1)$. Of note, 3 patients had no comorbidities. Twelve patients were receiving immunosuppressive therapy at the time of admission, including cancer chemotherapy $(n=9)$, calcineurin inhibitors $(n=5)$, such as tacrolimus or cyclosporine and steroids $(n=2)$. Six patients developed fusariosis while receiving antifungal agents for prophylaxis, specifically fluconazole $(n=4)$, micafungin $(n=1)$, and voriconazole $(n=1)$.

Skin was the most common site of infection $(\mathrm{n}=11$; 8 proven and 3 probable), followed by lung ( $n=8$ proven) and disseminated infection ( $\mathrm{n}=7 ; 4$ proven and 3 probable). No speciation of Fusarium species was performed by the clinical laboratory of MGH. The minimum inhibitory concentration (MIC) of antifungal agents was determined for 4 isolates. Two were resistant to voriconazole ( $\geq 8 \mu \mathrm{g} / \mathrm{mL}$ ) and 2 to both voriconazole and amphotericin $\mathrm{B}(\geq 8 \mu \mathrm{g} / \mathrm{mL})$.

The diagnosis of skin fusariosis was established with cultures from the skin growing Fusarium species $(\mathrm{n}=11)$ and skin biopsy $(n=8)$. Regarding the therapeutic management of skin fusariosis, 4 patients received medical treatment alone; 3 received combination therapy and died (liposomal amphotericin $\mathrm{B} /$ voriconazole: $\mathrm{n}=2$; and liposomal amphotericin $\mathrm{B} /$ micafungin: $\mathrm{n}=1$ ); and 1 received monotherapy with voriconazole and was cured. Five patients received both surgical and antifungal therapy; 3 received combination therapy (1 liposomal amphotericin $\mathrm{B} /$ micafungin and recovered, 1 voriconazole/micafungin and recovered, and 1 liposomal amphotericin B and voriconazole and died) and 2 received monotherapy (1 liposomal amphotericin B lost to follow-up and 1 voriconazole and recovered). Finally, 2 patients were treated surgically only and recovered. We note that 2 patients received granulocyte colony-stimulating factor (G-CSF) and G-CSF combined with granulocyte macrophage colony-stimulating factor (GM-CSF), respectively, for neutropenia (Table 2). Overall, 4 of 6 patients who received combination therapy died (66.7\% mortality), and 1 of them had undergone subsequent surgery. On the other hand, none of the patients who received monotherapy, surgical treatment alone, or monotherapy with surgical treatment died.
Patients with pulmonary fusariosis presented with shortness of breath $(\mathrm{n}=6)$, fever $(\mathrm{n}=6)$, cough $(\mathrm{n}=3)$, fatigue $(\mathrm{n}=2)$, and chest pain $(\mathrm{n}=1)$, and Fusarium species were isolated from bronchial washings $(n=7)$ and sputum $(n=1)$. Regarding the treatment administered, 4 patients received monotherapy and recovered (voriconazole: $\mathrm{n}=3$; itraconazole: $\mathrm{n}=1$ ), while 4 received combination therapy (2 liposomal amphotericin B/voriconazole and died, 1 liposomal amphotericin $\mathrm{B} /$ caspofungin and died, and 1 inhaled amphotericin B and oral voriconazole and recovered). Overall, 3 of 4 patients who were treated with combination therapy died ( $75 \%$ mortality), while none of the patients treated with monotherapy died. Of note, as shown in Tables 1 and 2, 5 of the 8 cases of pulmonary fusariosis have previously been described. ${ }^{17}$

Patients with disseminated fusariosis presented with various clinical symptoms, including nausea and vomiting $(\mathrm{n}=2)$, shortness of breath $(n=2)$, and fever $(n=1)$, and all of them had blood cultures positive for Fusarium species. Three patients were treated with combination therapy (liposomal amphotericin B/voriconazole, 2 died and 1 recovered), 3 patients received monotherapy with voriconazole and recovered, while 1 patient received no therapy and died (fusariosis was diagnosed after death). Overall, 2 of 3 patients who received combination therapy died $(66.7 \%$ mortality), while none of the patients treated with monotherapy died. Of note, as shown in Tables 1 and 2, 1 case of disseminated fusariosis has previously been reported. ${ }^{17}$

\section{Literature Review}

We identified 97 cases of invasive fusariosis from the literature published since $2000 .^{1-4,6-13,16,18,20-27,31-33,37-39,42-44,46}$ $48,50-57,59,61,62,65-67,69-71,74-81,83-85,87,89,91,97,99,100-103,105-108$, 111-113,115-121,124-126,128-135,139,140 The patients' mean age was 45 years (range, 3 mo to 85 yr). Fifty-four patients were male and 41 female (sex was not reported in 2 cases). Comorbidities included hematologic malignancies $(\mathrm{n}=60)$; neutropenia $(\mathrm{n}=$ $33)$; transplantation $(n=29)$ including hematopoietic stem cell transplant (HSCT; $n=18)$, renal transplant $(n=6)$, liver transplant $(\mathrm{n}=3)$, and lung transplant $(\mathrm{n}=2)$; diabetes mellitus $(\mathrm{n}=10)$, and burns $(n=2)$. Regarding the intake of medications at the time of admission, 33 patients were receiving chemotherapy, 24 steroids, and 12 a combination of chemotherapy and steroids.

Speciation was performed in 57 cases. The most common species were Fusarium solani $(\mathrm{n}=28)$, Fusarium oxysporum $(\mathrm{n}=12)$, and Fusarium verticillioides $(\mathrm{n}=5)$. Less common species included Fusarium dimerum $(\mathrm{n}=3)$, Fusarium proliferatum $(\mathrm{n}=3)$, Fusarium moniliforme $(\mathrm{n}=2)$, Fusarium falciforme $(\mathrm{n}=2)$, Fusarium acutatum $(\mathrm{n}=1)$, and Fusarium subglutinans $(\mathrm{n}=1)$.

Regarding the site of infection, 56 patients presented with skin involvement and 27 with disseminated infection, while the rest presented with pulmonary fusariosis $(n=3)$, infection of the nasal cavity $(n=2)$, peritonitis $(n=2)$, sinusitis $(n=1)$, and liver infection $(\mathrm{n}=1)$. In 5 cases the site of infection was not mentioned. Blood cultures were positive in 22 of the 27 cases with disseminated infection. The MIC to amphotericin B was measured for 14 isolates, and the MIC of voriconazole was measured in 12 of the 14 isolates. Thirteen isolates were susceptible to amphotericin $\mathrm{B}$, but only 8 isolates were susceptible to voriconazole.

Treatment was reported in 70 cases. In 32 cases, the treatment regimen was changed due to treatment failure or drug side effects (Table 3). Among patients with skin fusariosis, 35 received medical therapy alone, consisting of either monotherapy in 17 cases (voriconazole: $\mathrm{n}=7,6$ recovered; liposomal amphotericin $\mathrm{B}: \mathrm{n}=6$, 5 recovered; ketoconazole: $\mathrm{n}=2$, recovered; itraconazole: $\mathrm{n}=1$, recovered; and fluconazole: $\mathrm{n}=1$, recovered) or combination therapy in 18 cases (liposomal amphotericin B/voriconazole: $\mathrm{n}=12$, 
TABLE 2. Treatment and Outcome of $26 \mathrm{MGH}$ Patients

\begin{tabular}{|c|c|c|c|}
\hline \multicolumn{4}{|l|}{ Skin fusariosis $(\mathrm{n}=11)^{*}$} \\
\hline Medical therapy $(\mathrm{n}=9)$ & & Adjunct therapy $(\mathrm{n}=8)$ & Outcome \\
\hline \multirow[t]{6}{*}{ Combination therapy $(n=6)$} & Liposomal amphotericin B/voriconazole $(\mathrm{n}=3)$ & Surgery $(n=1)$ & Died \\
\hline & & G-CSF/GM-CSF $(n=1)$ & Died \\
\hline & & NA $(n=1)$ & Died \\
\hline & Liposomal amphotericin B/micafungin $(\mathrm{n}=2)$ & Surgery $(n=1)$ & Recovered \\
\hline & & NA $(n=1)$ & Died \\
\hline & Voriconazole/micafungin $(\mathrm{n}=1)$ & Surgery $(n=1)$ & Recovered \\
\hline \multirow[t]{2}{*}{ Monotherapy $(\mathrm{n}=3)$} & Voriconazole $(\mathrm{n}=2)$ & Surgery $(n=1)$ & Recovered \\
\hline & & NA $(n=1)$ & Recovered \\
\hline \multirow[t]{2}{*}{ No medical therapy $(\mathrm{n}=2)$} & Liposomal amphotericin B $(n=1)$ & Surgery and G-CSF $(n=1)$ & Lost to follow-up \\
\hline & & Surgery $(n=2)$ & Recovered \\
\hline \multicolumn{4}{|l|}{ Pulmonary fusariosis $(\mathrm{n}=8)$} \\
\hline Medical therapy $(\mathrm{n}=8)$ & & Adjunct therapy $(\mathrm{n}=0)$ & Outcome \\
\hline \multirow[t]{3}{*}{ Combination therapy $(n=4)$} & Liposomal amphotericin B/voriconazole $(\mathrm{n}=2)$ & NA & Died* \\
\hline & Liposomal amphotericin B/caspofungin $(\mathrm{n}=1)$ & & Died $\dagger$ \\
\hline & Inhaled amphotericin B/voriconazole $(\mathrm{n}=1)$ & & Recovered $\dagger$ \\
\hline \multirow[t]{2}{*}{ Monotherapy $(n=4)$} & Voriconazole $(\mathrm{n}=3)$ & & Recovered $\dagger$ \\
\hline & Itraconazole $(\mathrm{n}=1)$ & & Recovered* \\
\hline \multicolumn{4}{|c|}{ Disseminated fusariosis $(n=7)$} \\
\hline Medical therapy $(\mathrm{n}=6)$ & & Adjunct therapy $(\mathrm{n}=0)$ & Outcome \\
\hline \multirow[t]{3}{*}{ Combination therapy $(n=3)$} & Liposomal amphotericin B/voriconazole $(\mathrm{n}=1)$ & NA & Died $\dagger$ \\
\hline & Liposomal amphotericin B/voriconazole $(\mathrm{n}=2)$ & & Died* \\
\hline & Recovered* & & \\
\hline Monotherapy $(\mathrm{n}=3)$ & Voriconazole $(\mathrm{n}=3)$ & & Recovered* \\
\hline No medical therapy $(\mathrm{n}=1)$ & & & Died* \\
\hline
\end{tabular}

7 recovered; liposomal amphotericin $\mathrm{B} /$ flucytosine: $\mathrm{n}=2$, 1 recovered; liposomal amphotericin $B /$ fluconazole: $n=1$, recovered; liposomal amphotericin B/itraconazole: $\mathrm{n}=1$, recovered; itraconazole/terbinafine: $\mathrm{n}=1$, recovered; and liposomal amphotericin B/posaconazole/terbinafine: $n=1$, recovered). Two patients had the combination of surgery and antifungal monotherapy and recovered (amphotericin B: $\mathrm{n}=1$; and voriconazole: $\mathrm{n}=1$ ), while 3 underwent only surgery and recovered. We note that 9 patients received G-CSF because of neutropenia, while 1 received granulocytes, and 1 received the combination of G-CSF and granulocytes. Overall, 5 of the 16 patients who received combination therapy died $(31.3 \%$ mortality), while 2 of the 19 patients who received monotherapy died (10.5\% mortality).

Twenty-two patients with disseminated fusariosis received medical therapy only consisting of either monotherapy in 15 cases (liposomal amphotericin $\mathrm{B}: \mathrm{n}=8,7$ recovered; voriconazole: $\mathrm{n}=4$, recovered; itraconazole: $\mathrm{n}=1$, recovered; posaconazole: $\mathrm{n}=1$, recovered; and caspofungin: $\mathrm{n}=1$, recovered) or combination therapy in 7 cases (amphotericin B/fluconazole: $\mathrm{n}=2$, 1 recovered; amphotericin $\mathrm{B} /$ voriconazole: $\mathrm{n}=2$, recovered; amphotericin B/terbinafine: $\mathrm{n}=2,1$ recovered; and amphotericin $\mathrm{B}$ /posaconazole: $\mathrm{n}=1$, recovered), while 1 received surgical treatment and monotherapy with amphotericin B and recovered. Ten patients with disseminated disease received G-CSF for neutropenia, 1 received GM-CSF, and 1 received the combination of G-CSF and granulocytes. Overall, 3 of the 7 patients who received combination therapy died $(42.9 \%$ mortality), while 2 of the 16 patients who received monotherapy died (12.5\% mortality).

Three patients with pulmonary fusariosis received monotherapy and recovered (voriconazole: $\mathrm{n}=1$; amphotericin $\mathrm{B}$ deoxycholate: $\mathrm{n}=1$; and posaconazole: $\mathrm{n}=1$ ), 2 patients with nasal involvement received monotherapy with voriconazole and recovered, 2 patients with peritonitis received combination therapy and recovered (amphotericin B/flucytosine: $\mathrm{n}=1$; amphotericin $\mathrm{B} /$ ketoconazole: $\mathrm{n}=1$ ), 1 patient with sinusitis received monotherapy with amphotericin $\mathrm{B}$ and recovered, and 1 patient with liver involvement received monotherapy with amphotericin B and recovered.

\section{DISCUSSION}

Herein we present 26 patients with proven or probable invasive fusariosis treated at a general hospital (MGH patients) and review 97 cases reported since 2000. Hematologic malignancies, solid organ transplantation, HSCT, or immunosuppressive therapy were the predominant underlying conditions, and the skin was the predominant site of infection in both MGH and literature cases. The most frequently identified species among literature patients were members of the Fusarium solani complex (49\%; 29 of 59 isolates). The clinical presentation varied depending on the infected site; diagnosis was established with biopsy and culture. Blood cultures were positive in $86 \%$ of MGH patients and $82 \%$ of literature patients with disseminated fusariosis $(82 \%$ of 


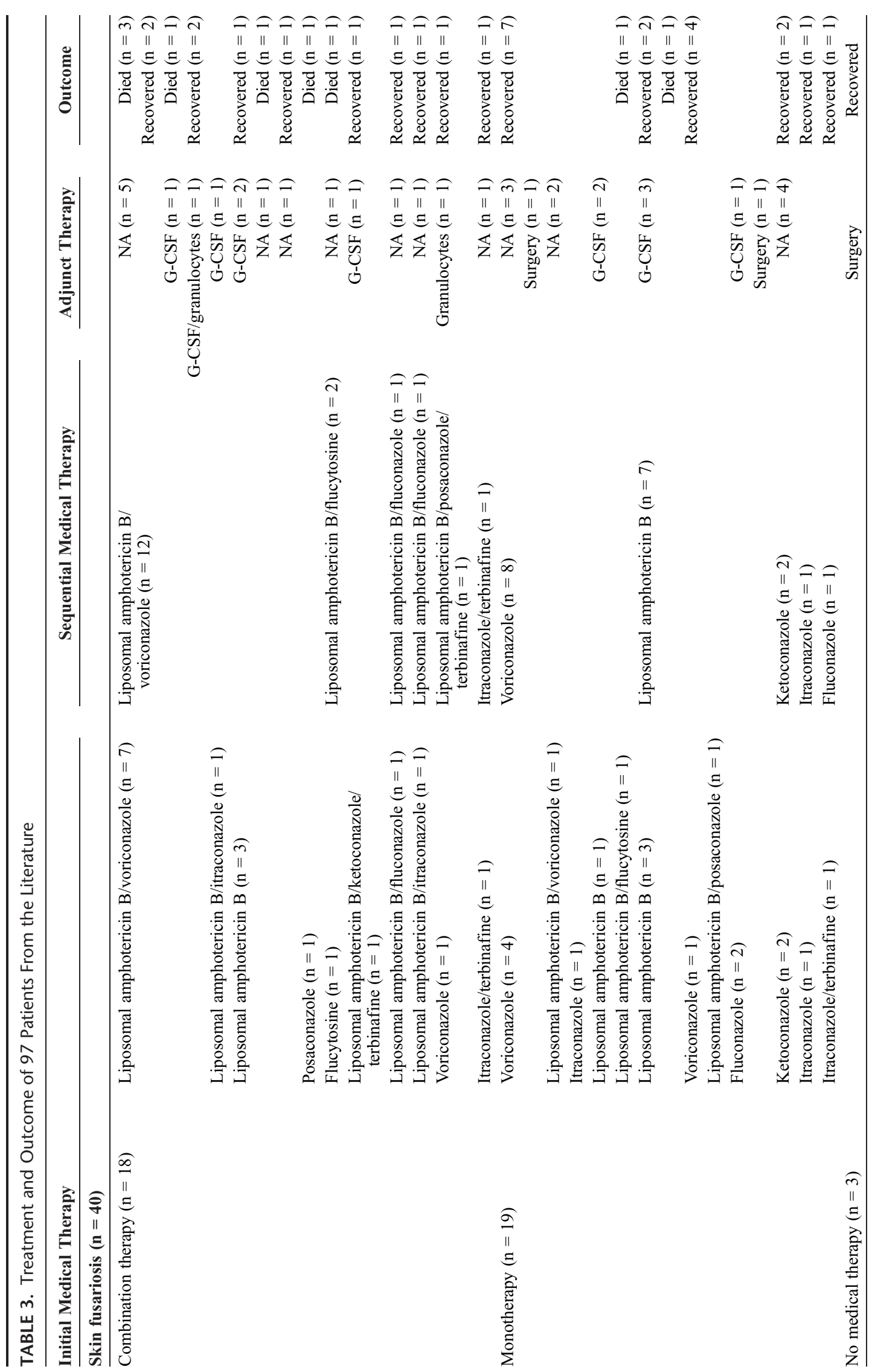




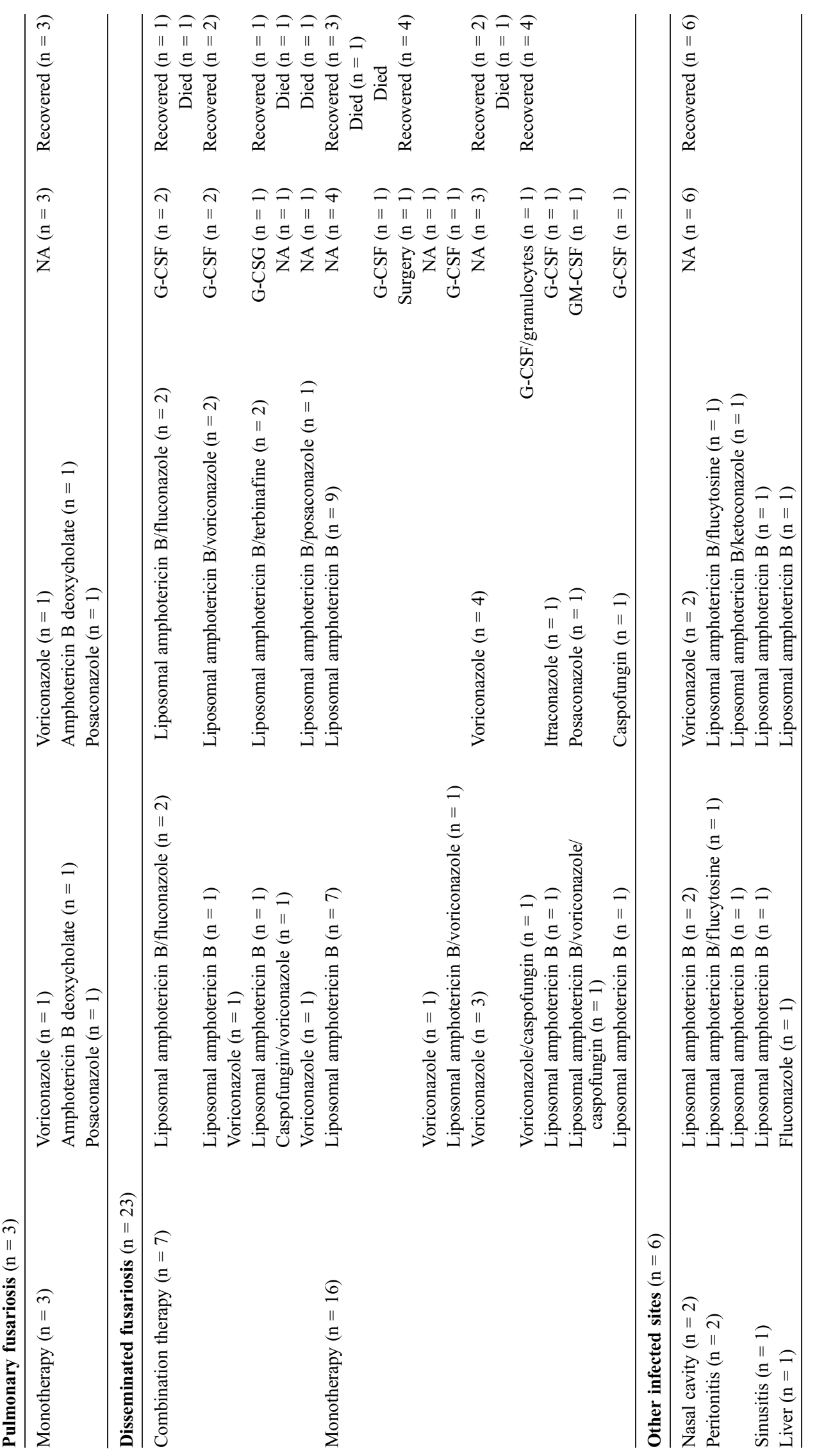


all patients with disseminated disease). The most commonly used therapeutic scheme in $\mathrm{MGH}$ patients was monotherapy with voriconazole ( $\mathrm{n}=8,0 \%$ mortality), followed by the combination of amphotericin $\mathrm{B} /$ voriconazole $(\mathrm{n}=8,87.5 \%$ mortality). On the contrary, literature patients were more frequently treated with monotherapy with amphotericin B ( $\mathrm{n}=19,10.5 \%$ mortality), followed by the administration of voriconazole as monotherapy $(\mathrm{n}=15,6.7 \%$ mortality) and the combination of amphotericin $\mathrm{B} /$ voriconazole ( $\mathrm{n}=14,35.7 \%$ mortality). Overall, the mortality rates of patients receiving combination therapy were higher than those of patients receiving monotherapy in both MGH and literature patients and for all infected sites. Also, patients who underwent surgical intervention exhibited lower mortality rates than patients treated with antifungal agents only.

Fusarium species are ubiquitous in the environment ${ }^{90}$ and can be found in soil and water. ${ }^{34,36,90,95}$ In humans, Fusarium species cause a wide spectrum of diseases, ranging from superficial to locally invasive and disseminated infections. ${ }^{14,19,40,41}$, $47,58,64,68,73,82,88,90,93,95,110,114,122,123,127$ Invasive and disseminated fusariosis occurs mostly in patients with compromised immune systems, and especially neutropenia. ${ }^{9,15,17,92,95,96,98,104,136}$ In fact, in our study $61.5 \%$ of MGH patients and $100 \%$ of literature patients were immunocompromised. The most frequent underlying disease in both the MGH and the published cases was hematologic malignancies ( $53 \%$ of patients overall), $5,45,60,92,102$ while other major underlying diseases included solid organ transplantation ( $15 \%$ of patients overall) and HSCT $(15 \%$ of patients overall). Also, the majority of patients $(63 \%$ of patients overall) were receiving immunosuppressive regimens at the time of diagnosis of fusariosis, and $31 \%$ were neutropenic.

Although the clinical presentation of invasive fusariosis is highly variable, high fever that is not responsive to antimicrobial therapy is relatively common in neutropenic patients. Respiratory infections also occur frequently, while skin involvement represents either a primary site of infection or metastatic lesions from disseminated disease ${ }^{11,93,95}$ and manifests as papules, nodules, areas of necrosis, mycetomas, target lesions, or bullae. ${ }^{93,95,132,138}$ In the current study, the skin was one of the main sites of infection (54\% of patients overall). Since fusariosis leads to fatal outcomes without treatment or when treatment is delayed, skin lesions in immunocompromised patients should be investigated aggressively. ${ }^{11,30,93}$

The diagnosis of fusariosis is mainly based on culture of infected sites and histopathology, which require more than 5-7 days. ${ }^{95}$ This can cause a delay in treatment and result in fatalities. Moreover, the microscopic characteristics of Fusarium species are not always distinguishable from other molds, especially Aspergillus species, and therefore identification requires significant expertise. ${ }^{95}$ In addition, immunocompromised patients often receive prophylaxis with antifungal medications, which turn cultures for Fusarium species negative and render diagnosis more difficult. Thus, non-culture methods such as polymerase chain reaction (PCR) may be superior for detecting Fusarium species. ${ }^{55,56,63,71,72,95,137}$

Since there are not enough data to support a solid evidencebased approach to the treatment of invasive fusariosis, improvement in this domain is mandatory. Medical intervention remains the mainstay of treatment. ${ }^{17}$ Amphotericin B monotherapy is considered an effective therapeutic approach in immunocompromised patients, according to previously published studies. Specifically, in a retrospective study, amphotericin B cured or stabilized 15 of 26 patients with invasive fusariosis. ${ }^{109}$ Moreover, posaconazole has been reported as a successful salvage treatment for patients with invasive fusariosis. ${ }^{111}$ Most clinicians start with either amphotericin B or voriconazole as first-line therapy. ${ }^{86}$
In the current study, amphotericin B was used as monotherapy in $1 \mathrm{MGH}$ patient, who recovered, and in $19.6 \%$ of literature patients with a mortality rate of $10.5 \%$. Voriconazole was also commonly administered $(30.8 \%$ of MGH patients and $15.5 \%$ of literature cases, with mortality rates of $0 \%$ and $6.7 \%$, respectively). Finally, the combination of amphotericin B/voriconazole was used in $30.8 \%$ of MGH patients and $14.4 \%$ of literature cases with mortality rates of $87.5 \%$ and $35.7 \%$, respectively. These results show that monotherapy with voriconazole and monotherapy with amphotericin B are both successful in treating invasive fusariosis, since the difference in mortality is not significant.

Among patients with skin fusariosis, for MGH patients the mortality for those treated with combination therapy was $66.7 \%$ compared with $0 \%$ mortality for those treated with monotherapy, and for literature patients the mortality was $31.3 \%$ for those treated with combination therapy compared with $10.5 \%$ for those treated with monotherapy. MGH patients with pulmonary fusariosis had a mortality rate of $75 \%$, while none of the literature patients treated with monotherapy died. Finally, disseminated disease led to a mortality rate of $66.7 \%$ in $\mathrm{MGH}$ patients treated with combination therapy compared to $0 \%$ in those treated with monotherapy, while the mortality rates for literature patients were $42.9 \%$ and $12.5 \%$, respectively. The higher mortality rates of patients who received combination therapy may be explained by the fact that more severely ill patients tend to receive more medications and thus are more likely to be treated with combination therapy. Overall, the most effective antifungal therapy should be based on Fusarium species susceptibility testing. Although in the present series, the MIC of antifungal agents was determined for only 6 isolates, the resistance profiles of some of these isolates highlight the emerging resistance of Fusarium species to traditional antifungal regimens. ${ }^{60}$

Finally, surgery was performed in $7 \mathrm{MGH}$ patients with skin fusariosis (14.3\% mortality), 5 literature patients with skin fusariosis $(0 \%$ mortality), and 1 literature patient with disseminated infection ( $0 \%$ mortality). The mortality rates of patients who underwent surgery were lower compared to those who did not have surgery (rates of $75 \%, 19.4 \%$, and $8.7 \%$, respectively). This finding suggests that the surgical removal of focal lesions may result in better outcomes and thus should be considered for patients with skin or disseminated infections.

Despite medical intervention, invasive fusariosis has been linked to a high mortality rate. In the current report, the mortality rate was $50 \%$ among the MGH patients with disseminated fusariosis, $40 \%$ among patients with skin fusariosis, and $37.5 \%$ among patients with lung fusariosis. On the other hand, the mortality rates of the literature patients with disseminated, skin, and pulmonary fusariosis were $30 \%, 18 \%$, and $0 \%$, respectively. The higher mortality rates of the MGH patients in the current series may be attributed to their comorbidities, and the lower mortality rates of the literature patients may be due to a "publication bias." A representative example of more comorbidities among MGH patients is the presence of burns $(7.7 \%, \mathrm{n}=7$ MGH patients vs $2.1 \%, n=2$ literature patients). This difference may lead to the observation of a higher mortality in the MGH patient population and may be explained by the fact that most case reports in the literature present patients with a favorable outcome and thus with fewer comorbidities. We note that 6 of 7 patients with burns had skin fusariosis. However, a true association between burns and skin fusariosis is difficult to establish, because of the small sample size of the MGH cohort.

In conclusion, the results of the current study suggest that monotherapy with voriconazole is equally effective to monotherapy with amphotericin B for the treatment of invasive fusariosis, and that the addition of surgery leads to better outcomes in patients 
with skin and disseminated fusariosis. More studies with larger sample sizes that will allow for stratification of the outcomes by disease severity are required to investigate the difference in the effectiveness of combination medical therapy versus monotherapy, with the low prevalence of invasive fusariosis being a limiting factor.

\section{REFERENCES}

1. Albisetti M, Lauener RP, Gungor T, Schar G, Niggli FK, Nadal D. Disseminated Fusarium oxysporum infection in hemophagocytic lymphohistiocytosis. Infection. 2004;32:364-366.

2. Anandi V, Vishwanathan P, Sasikala S, Rangarajan M, Subramaniyan CS, Chidambaram N. Fusarium solani breast abscess. Indian J Med Microbiol. 2005;23:198-199.

3. Anten S, Heddema ER, Visser O, Zweegman AS. Images in haematology. Cerebral fungal abscess in a patient with acute promyelocytic leukaemia. Br J Haematol. 2008;140:253.

4. Apostolidis J, Bouzani M, Platsouka E, Belasiotou H, Stamouli M, Harhalakis N, Boutati EI, Paniara O, Nikiforakis E. Resolution of fungemia due to Fusarium species in a patient with acute leukemia treated with caspofungin. Clin Infect Dis. 2003;36:1349-1350.

5. Aquino VR, Vercosa EB, Falhauber G, Lunardi LW, Silla L, Pasqualotto AC. Distribution of filamentous fungi causing invasive fungal disease at the Haematological Unit, Hospital de Clinicas de Porto Alegre, Brazil. Braz J Infect Dis. 2010;14:277-280.

6. Austen B, McCarthy H, Wilkins B, Smith A, Duncombe A. Fatal disseminated fusarium infection in acute lymphoblastic leukaemia in complete remission. J Clin Pathol. 2001;54:488-490.

7. Bader M, Jafri AK, Krueger T, Kumar V. Fusarium osteomyelitis of the foot in a patient with diabetes mellitus. Scand J Infect Dis. 2003;35:895-896.

8. Banerji JS, Singh JC. Cutaneous Fusarium infection in a renal transplant recipient: a case report. $J$ Med Case Reports. 2011;5:205.

9. Barrios NJ, Kirkpatrick DV, Murciano A, Stine K, Van Dyke RB, Humbert JR. Successful treatment of disseminated Fusarium infection in an immunocompromised child. $J$ Pediatr Hematol Oncol. 1990;12:319-324.

10. Bibashi E, Kokolina E, Sigler L, Sofianou D, Tsakiris D, Visvardis G, Papadimitriou M, Memmos D. Three cases of uncommon fungal peritonitis in patients undergoing peritoneal dialysis. Perit Dial Int. 2002;22:523-525.

11. Bodey GP, Boktour M, Mays S, Duvic M, Kontoyiannis D, Hachem R, Raad I. Skin lesions associated with Fusarium infection. $J$ Am Acad Dermatol. 2002;47:659-666.

12. Bose P, Parekh HD, Holter JL, Greenfield RA. Disseminated fusariosis occurring in two patients despite posaconazole prophylaxis. J Clin Microbiol. 2011;49:1674-1675.

13. Bourgeois GP, Cafardi JA, Sellheyer K, Andea AA. Disseminated Fusarium infection originating from paronychia in a neutropenic patient: a case report and review of the literature. Cutis. 2010;85:191-194

14. Bourguignon RL, Walsh AF, Flynn JC, Baro C, Spinos E. Fusarium species osteomyelitis. Case report. J Bone Joint Surg Am. 1976;58:722-723.

15. Boutati EI, Anaissie EJ. Fusarium, a significant emerging pathogen in patients with hematologic malignancy: ten years' experience at a cancer center and implications for management. Blood. 1997; 90:999-1008.

16. Busemann C, Kruger W, Schwesinger G, Kallinich B, Schroder G, Abel P, Kiefer T, Neumann T, Dolken G. Myocardial and aortal involvement in a case of disseminated infection with Fusarium solani after allogeneic stem cell transplantation: report of a case. Mycoses. 2009;52:372-376

17. Carneiro HA, Coleman JJ, Restrepo A, Mylonakis E. Fusarium infection in lung transplant patients: report of 6 cases and review of the literature. Medicine (Baltimore). 2011;90:69-80.

18. Cesaro S, Marinello S, Alessia B, Alaggio R, Rossi L, Toffolutti T, Putti MC, Gamba P. Successful treatment of disseminated fusariosis in a child with acute myelogenous leukaemia with medical and surgical approach. Mycoses. 2010;53:181-185.

19. Chang DC, Grant GB, O’Donnell K, Wannemuehler KA, Noble-Wang J, Rao CY, Jacobson LM, Crowell CS, Sneed RS, Lewis FM, Schaffzin JK, Kainer MA, Genese CA, Alfonso EC, Jones DB, Srinivasan A, Fridkin SK, Park BJ. Multistate outbreak of Fusarium keratitis associated with use of a contact lens solution. JAMA. 2006;296:953-963.

20. Chi CC, Wang SH. Disseminated cutaneous Fusarium moniliforme infections in a leukemic child. Int J Dermatol. 2007;46:487-489.

21. Cocchi S, Codeluppi M, Venturelli C, Bedini A, Grottola A, Gennari W, Cavrini F, Di Benedetto F, De Ruvo N, Rumpianesi F, Gerunda GE, Guaraldi G. Fusarium verticillioides fungemia in a liver transplantation patient: successful treatment with voriconazole. Diagn Microbiol Infect Dis. 2011;71:438-441.

22. Consigny S, Dhedin N, Datry A, Choquet S, Leblond V, Chosidow O. Successsful voriconazole treatment of disseminated fusarium infection in an immunocompromised patient. Clin Infect Dis. 2003;37:311-313.

23. Cooke NS, Feighery C, Armstrong DK, Walsh M, Dempsey S. Cutaneous Fusarium solani infection in childhood acute lymphoblastic leukaemia. Clin Exp Dermatol. 2009;34:117-119.

24. Cudillo L, Girmenia C, Santilli S, Picardi A, Dentamaro T, Tendas A, de Fabritiis P. Breakthrough fusariosis in a patient with acute lymphoblastic leukemia receiving voriconazole prophylaxis. Clin Infect Dis. 2005;40:1212-1213.

25. Cudillo L, Tendas A, Picardi A, Dentamaro T, Del Principe MI, Amadori S, de Fabritiis P. Successful treatment of disseminated fusariosis with high dose liposomal amphotericin-B in a patient with acute lymphoblastic leukemia. Ann Hematol. 2006;85:136-138.

26. Cuellar-Rodriguez J, Bravo LT, Oethinger M, Fraser T, Mossad SB. Disseminated fusariosis in a recipient of a bone-marrow transplant. Lancet Infect Dis. 2009;9:520.

27. Dai W, Dharamsi JW, Soliman S, Ricotti C, Gander R, Bergstresser P, Chan J. Cutaneous fusariosis developing in a post-irradiation site. Dermatol Online J. 2011;17:5.

28. De Pauw B, Walsh TJ, Donnelly JP, Stevens DA, Edwards JE, Calandra T, Pappas PG, Maertens J, Lortholary O, Kauffman CA, Denning DW, Patterson TF, Maschmeyer G, Bille J, Dismukes WE, Herbrecht R, Hope WW, Kibbler CC, Kullberg BJ, Marr KA, Munoz P, Odds FC, Perfect JR, Restrepo A, Ruhnke M, Segal BH, Sobel JD, Sorrell TC, Viscoli C, Wingard JR, Zaoutis T, Bennett JE. Revised definitions of invasive fungal disease from the European Organization for Research and Treatment of Cancer/Invasive Fungal Infections Cooperative Group and the National Institute of Allergy and Infectious Diseases Mycoses Study Group (EORTC/MSG) Consensus Group. Clin Infect Dis. 2008;46:1813-1821

29. Dignani MC, Anaissie E. Human fusariosis. Clin Microbiol Infect. 2004;10:67-75

30. Doczi I, Gyetvai T, Kredics L, Nagy E. Involvement of Fusarium spp. in fungal keratitis. Clin Microbiol Infect. 2004;10:773-776.

31. Dornbusch HJ, Buzina W, Summerbell RC, Lass-Florl C, Lackner H, Schwinger W, Sovinz P, Urban C. Fusarium verticillioides abscess of the nasal septum in an immunosuppressed child: case report and identification of the morphologically atypical fungal strain. J Clin Microbiol. 2005;43:1998-2001.

32. Durand-Joly I, Alfandari S, Benchikh Z, Rodrigue M, Espinel-Ingroff A, Catteau B, et al. Successful outcome of disseminated Fusarium 
infection with skin localization treated with voriconazole and amphotericin B-lipid complex in a patient with acute leukemia. J Clin Microbiol. 2003;41:4898-4900.

33. Edupuganti S, Rouphael N, Mehta A, Eaton M, Heller JG, Bressler A, Brandt M, O'Donnell K. Fusarium falciforme vertebral abscess and osteomyelitis: case report and molecular classification. J Clin Microbiol. 2011;49:2350-2353.

34. Elvers KT, Leeming K, Moore CP, Lappin-Scott HM. Bacterial-fungal biofilms in flowing water photo-processing tanks. $J$ Appl Microbiol. 1998;84:607-618

35. Enoch DA, Ludlam HA, Brown NM. Invasive fungal infections: a review of epidemiology and management options. J Med Microbiol. 2006;55:809-818.

36. Evans J, Levesque D, de Lahunta A, Jensen HE. Intracranial fusariosis: a novel cause of fungal meningoencephalitis in a dog. Vet Pathol. 2004;41:510-514

37. Fan Y, Willems L, Leboeuf C, Li W, Lacroix C, Robin M, Socie G, Ribaud P, Verneuil L, Janin A. Skin microvascular thrombosis in Fusarium infection in two early biopsied cases. Case Rep Dermatol. 2010;2:76-81

38. Feramisco JD, Hsiao JL, Fox LP, Ruben BS. Angioinvasive Fusarium and concomitant Enterococcus infection arising in association with leukemia cutis. J Cutan Pathol. 2011;38:926-929.

39. Fergie JE, Huang DB, Purcell K, Milligan T. Successful treatment of Fusarium solani ecthyma gangrenosum in a child with acute lymphoblastic leukemia in relapse. Pediatr Infect Dis $J$. 2000;19:579-581.

40. Flynn JT, Meislich D, Kaiser BA, Polinsky MS, Baluarte HJ. Fusarium peritonitis in a child on peritoneal dialysis: case report and review of the literature. Perit Dial Int. 1996;16:52-57.

41. Gabriele P, Hutchins RK. Fusarium endophthalmitis in an intravenous drug abuser. Am J Ophthalmol. 1996;122:119-121.

42. Garbino J, Uckay I, Rohner P, Lew D, Van Delden C. Fusarium peritonitis concomitant to kidney transplantation successfully managed with voriconazole: case report and review of the literature. Transpl Int. 2005;18:613-618

43. Gaur S, Rajgopal A, Ashbee R. A successfully treated case of peritonitis due to Fusarium dimerum. J Infect. 2010;61:86-88.

44. Geddes ER, Polder K, Cutlan JE, Torres-Cabala CA, Hymes SR. Ulcerated plaque under a ruby ring in an immunosuppressed patient. Dermatol Online J. 2010;16:4.

45. Girmenia C, Pagano L, Corvatta L, Mele L, del Favero A, Martino P. The epidemiology of fusariosis in patients with haematological diseases. Gimema Infection Programme. Br J Haematol. 2000;111:272-276

46. Gorman SR, Magiorakos AP, Zimmerman SK, Craven DE. Fusarium oxysporum pneumonia in an immunocompetent host. South Med J. 2006;99:613-616.

47. Grant GB, Fridkin S, Chang DC, Park BJ. Postrecall surveillance following a multistate fusarium keratitis outbreak, 2004 through 2006. JAMA. 2007;298:2867-2868.

48. Guarro J, Nucci M, Akiti T, Gene J, Barreiro MD, Goncalves RT. Fungemia due to Fusarium sacchari in an immunosuppressed patient. J Clin Microbiol. 2000;38:419-421.

49. Guilhermetti E, Takahachi G, Shinobu CS, Svidzinski TI. Fusarium spp. as agents of onychomycosis in immunocompetent hosts. Int $J$ Dermatol. 2007;46:822-826.

50. Guimera-Martin-Neda F, Garcia-Bustinduy M, Noda-Cabrera A, Sanchez-Gonzalez R, Montelongo RG. Cutaneous infection by Fusarium: successful treatment with oral voriconazole. Br J Dermatol. 2004;150:777-778
51. Gupta S, Almyroudis NG, Battiwalla M, Bambach BJ, McCarthy PL, Proefrock AD, Ball D, Paplham P, Varma A, Kwon-Chung J, Segal BH. Successful treatment of disseminated fusariosis with posaconazole during neutropenia and subsequent allogeneic hematopoietic stem cell transplantation. Transpl Infect Dis. 2007;9:156-160.

52. Gurusidappa SB, Mamatha HS. Fusarial skin lesion in immunocompromised. Indian J Cancer. 2011;48:116-117.

53. Guzman-Cottrill JA, Zheng X, Chadwick EG. Fusarium solani endocarditis successfully treated with liposomal amphotericin B and voriconazole. Pediatr Infect Dis J. 2004;23:1059-1061

54. Halpern M, Balbi E, Carius L, Roma J, Gonzalez AC, Agoglia L, Covelo M, Araujo A, Guedes C, Alves J, Enne M, Martinho JM, Pacheco L. Cellulitis and nodular skin lesions due to Fusarium spp in liver transplant: case report. Transplant Proc. 2010;42:599-600.

55. Healy M, Reece K, Walton D, Huong J, Frye S, Raad II, Kontoyiannis DP. Use of the Diversi Lab System for species and strain differentiation of Fusarium species isolates. J Clin Microbiol. 2005;43:5278-5280.

56. Hennequin C, Abachin E, Symoens F, Lavarde V, Reboux G, Nolard N, Berche P. Identification of Fusarium species involved in human infections by $28 \mathrm{~S}$ rRNA gene sequencing. J Clin Microbiol. 1999;37:3586-3589

57. Herbrecht R, Kessler R, Kravanja C, Meyer MH, Waller J, Letscher-Bru V. Successful treatment of Fusarium proliferatum pneumonia with posaconazole in a lung transplant recipient. J Heart Lung Transplant. 2004;23:1451-1454.

58. Hilmioglu-Polat S, Metin DY, Inci R, Dereli T, Kilinc I, Tumbay E. Non-dermatophytic molds as agents of onychomycosis in Izmir, Turkey - a prospective study. Mycopathologia. 2005;160:125-128.

59. Ho DY, Lee JD, Rosso F, Montoya JG. Treating disseminated fusariosis amphotericin B, voriconazole or both? Mycoses. 2007;50:227-231.

60. Hsiue HC, Ruan SY, Kuo YL, Huang YT, Hsueh PR. Invasive infections caused by non-Aspergillus moulds identified by sequencing analysis at a tertiary care hospital in Taiwan, 2000-2008. Clin Microbiol Infect. 2010;16:1204-1206.

61. Hsu CK, Hsu MM, Lee JY. Fusariosis occurring in an ulcerated cutaneous CD8+ T cell lymphoma tumor. Eur J Dermatol. 2006;16:297-301.

62. Huang WW, Gray C, Bowers R, Walk N, Lind A, Hornstra I. Painful necrotic nodules in an immunocompromised patient. Arch Dermatol. 2010;146:439-444

63. Hue FX, Huerre M, Rouffault MA, de Bievre C. Specific detection of fusarium species in blood and tissues by a PCR technique. J Clin Microbiol. 1999;37:2434-2438.

64. Jakle C, Leek JC, Olson DA, Robbins DL. Septic arthritis due to Fusarium solani. J Rheumatol. 1983;10:151-153.

65. Jossi M, Ambrosioni J, Macedo-Vinas M, Garbino J. Invasive fusariosis with prolonged fungemia in a patient with acute lymphoblastic leukemia: case report and review of the literature. Int J Infect Dis. 2010;14:354-356.

66. Kapp M, Schargus M, Deuchert T, Springer J, Wendel F, Loeffler J, Grigoleit GU, Kurzai O, Heinz W, Einsele H, Stuhler G. Endophthalmitis as primary clinical manifestation of fatal fusariosis in an allogeneic stem cell recipient. Transpl Infect Dis. 2011;13:374-379.

67. Katkar VJ, Tankhiwale SS, Kurhade A. Fusarium soloni mycetoma Indian J Dermatol. 2011;56:315-317.

68. Kerr CM, Perfect JR, Craven PC, Jorgensen JH, Drutz DJ, Shelburne JD, Gallis HA, Gutman RA. Fungal peritonitis in patients on continuous ambulatory peritoneal dialysis. Ann Intern Med. 1983;99:334-336.

69. Khoury H, Ball NJ. Disseminated fusariosis in a patient with acute leukaemia. Br J Haematol. 2003;120:1

70. King BA, Seropian S, Fox LP. Disseminated fusarium infection with muscle involvement. J Am Acad Dermatol. 2011;65:235-237. 
71. Kleinschmidt-Demasters BK. Disseminated Fusarium infection with brain abscesses in a lung transplant recipient. Clin Neuropathol. 2009;28:417-421.

72. Kourkoumpetis TK, Fuchs BB, Coleman JJ, Desalermos A, Mylonakis E. Polymerase chain reaction-based assays for the diagnosis of invasive fungal infections. Clin Infect Dis. 2012;54:1322-1331.

73. Kurien M, Anandi V, Raman R, Brahmadathan KN. Maxillary sinus fusariosis in immunocompetent hosts. J Laryngol Otol. 1992;106:733-736.

74. Labois A, Gray C, Lepretre S. Successful treatment of disseminated fusariosis with voriconazole in an acute lymphoblastic leukaemia patient. Mycoses. 2011;54:8-11.

75. Latenser BA. Fusarium infections in burn patients: a case report and review of the literature. J Burn Care Rehabil. 2003;24:285-288.

76. Letscher-Bru V, Campos F, Waller J, Randriamahazaka R, Candolfi E, Herbrecht R. Successful outcome of treatment of a disseminated infection due to Fusarium dimerum in a leukemia patient. $J$ Clin Microbiol. 2002;40:1100-1102.

77. Lipovy B, Rihova H, Hanslianova M, Kocmanova I, Zaloudikova Z, Kaloudova Y, Suchanek I, Mager R, Krupicová H, Slezak M, Datko M, Brychta P, Sevcikova A. Unsuccessful therapy of combined mycotic infection in a severely burned patient: a case study. Acta Chir Plast. 2009;51:83-84.

78. Lodato F, Tame MR, Montagnani M, Sambri V, Liguori G, Azzaroli F, Costigliola P, Grazi G, Roda E, Mazzella G. Systemic fungemia and hepatic localizations of Fusarium solani in a liver transplanted patient: an emerging fungal agent. Liver Transpl. 2006;12:1711-1714.

79. LO Nigro L, Di Cataldo A, Ragusa R. Successful treatment of Fusarium (spp.) infection in a child with acute lymphoblastic leukemia. Med Pediatr Oncol. 2000;34:356-357.

80. Macedo DP, Neves RP, Fontan J, Souza-Motta CM, Lima D. A case of invasive rhinosinusitis by Fusarium verticillioides (Saccardo) Nirenberg in an apparently immunocompetent patient. Med Mycol. 2008;46:499-503.

81. Madariaga MG, Kohl S. Disseminated fusariosis presenting with pulmonary nodules following a line infection. Braz J Infect Dis. 2006;10:419.

82. Madhavan M, Ratnakar C, Veliath AJ, Kanungo R, Smile SR, Bhat S Primary disseminated fusarial infection. Postgrad Med J. 1992;68:143-144.

83. Mansur AT, Artunkal S, Ener B. Fusarium oxysporum infection of stasis ulcer: eradication with measures aimed to improve stasis. Mycoses. 2009;54:205-207.

84. Mellouli F, Ksouri H, Barbouche R, Maamer M, Hamed LB, Hmida S, Hassen AB, Bejaoui M. Successful treatment of Fusarium solani ecthyma gangrenosum in a patient affected by leukocyte adhesion deficiency type 1 with granulocytes transfusions. BMC Dermatol. 2010;10:10.

85. Mikulska M, Furfaro E, Del Bono V, Gualandi F, Raiola AM, Molinari MP, Gritti P, Sanguinetti M, Posteraro B, Bacigalupo A, Viscoli C. Galactomannan testing might be useful for early diagnosis of fusariosis. Diagn Microbiol Infect Dis. 2012;72:367-369.

86. Muhammed M, Coleman JJ, Carneiro HA, Mylonakis E. The challenge of managing fusariosis. Virulence. 2011;2:91-96.

87. Muller C, Schumacher U, Gregor M, Lamprecht G. How immunocompromised are short bowel patients receiving home parenteral nutrition? Apropos a case of disseminated Fusarium oxysporum sepsis. JPEN J Parenter Enteral Nutr. 2009;33:717-720.

88. Murray CK, Beckius ML, McAllister K. Fusarium proliferatum superficial suppurative thrombophlebitis. Mil Med. 2003;168:426-427.

89. Nakamura Y, Xu X, Saito Y, Tateishi T, Takahashi T, Kawachi Y, Otsuka F. Deep cutaneous infection by Fusarium solani in a healthy child: successful treatment with local heat therapy. J Am Acad Dermatol. 2007;56:873-877

90. Nelson PE, Dignani MC, Anaissie EJ. Taxonomy, biology, and clinical aspects of Fusarium species. Clin Microbiol Rev. 1994;7:479-504.

91. Neuburger S, Massenkeil G, Seibold M, Lutz C, Tamm I, le Coutre P, Graf B, Doerken B, Arnold R. Successful salvage treatment of disseminated cutaneous fusariosis with liposomal amphotericin B and terbinafine after allogeneic stem cell transplantation. Transpl Infect Dis. 2008;10:290-293.

92. Nir-Paz R, Strahilevitz J, Shapiro M, Keller N, Goldschmied-Reouven A, Yarden O, Block C, Polacheck I. Clinical and epidemiological aspects of infections caused by fusarium species: a collaborative study from Israel. J Clin Microbiol. 2004;42:3456-3461.

93. Nucci M, Anaissie E. Cutaneous infection by Fusarium species in healthy and immunocompromised hosts: implications for diagnosis and management. Clin Infect Dis. 2002;35:909-920.

94. Nucci M, Anaissie E. Emerging fungi. Infect Dis Clin North Am. 2006;20:563-579.

95. Nucci M, Anaissie E. Fusarium infections in immunocompromised patients. Clin Microbiol Rev. 2007;20:695-704.

96. Nucci M, Anaissie EJ, Queiroz-Telles F, Martins CA, Trabasso P, Solza C, Mangini C, Simoes BP, Colombo AL, Vaz J, Levy CE, Costa S, Moreira VA, Oliveira JS, Paraguay N, Duboc G, Voltarelli JC, Maiolino A, Pasquini R, Souza CA. Outcome predictors of 84 patients with hematologic malignancies and Fusarium infection. Cancer. 2003;98:315-319

97. Nucci M, Marr KA. Emerging fungal diseases. Clin Infect Dis. 2005;41:521-526.

98. Nucci M, Marr KA, Queiroz-Telles F, Martins CA, Trabasso P, Costa S, Voltarelli JC, Colombo AL, Imhof A, Pasquini R, Maiolino A, Souza CA, Anaissie E. Fusarium infection in hematopoietic stem cell transplant recipients. Clin Infect Dis. 2004;38:1237-1242.

99. Nunes MD, Barbosa FB, Gomes GH, Braulio R, Nicoliello MF, Ferrari TC. Fatal right-sided endocarditis caused by Fusarium in an immunocompromised patient: a case report. Mycoses. 2011;54:460-462.

100. Okada H, Hamatani S, Kondo M, Imai T, Itoh S, Isobe K, Onishi S Successful treatment of disseminated Fusarium infection in an infant with leukemia. Int J Hematol. 2000;72:494-498.

101. Oliveira JS, Kerbauy FR, Colombo AL, Bahia DM, Pinheiro GS, Silva MR, Ribeiro MS, Raineri G, Kerbauy J. Fungal infections in marrow transplant recipients under antifungal prophylaxis with fluconazole. Braz J Med Biol Res. 2002;35:789-798.

102. Pagano L, Girmenia C, Mele L, Ricci P, Tosti ME, Nosari A, Buelli M, Picardi M, Allione B, Corvatta L, D'Antonio D, Montillo M, Melillo L, Chierichini A, Cenacchi A, Tonso A, Cudillo L, Candoni A, Savignano C, Bonini A, Martino P, Del Favero A. Infections caused by filamentous fungi in patients with hematologic malignancies. A report of 391 cases by GIMEMA Infection Program. Haematologica. 2001;86:862-870.

103. Palmore TN, Shea YR, Childs RW, Sherry RM, Walsh TJ. Fusarium proliferatum soft tissue infection at the site of a puncture by a plant: recovery, isolation, and direct molecular identification. J Clin Microbiol. 2010;48:338-342.

104. Park BJ, Pappas PG, Wannemuehler KA, Alexander BD, Anaissie EJ, Andes DR, Baddley JW, Brown JM, Brumble LM, Freifeld AG, Hadley S, Herwaldt L, Ito JI, Kauffman CA, Lyon GM, Marr KA, Morrison VA, Papanicolaou G, Patterson TF, Perl TM, Schuster MG, Walker R, Wingard JR, Walsh TJ, Kontoyiannis DP. Invasive non-Aspergillus mold infections in transplant recipients, United States, 2001-2006. Emerg Infect Dis. 2011;17:1855-1864.

105. Patterson TF, Mackool BT, Gilman MD, Piris A. Case records of the Massachusetts General Hospital. Case 22-2009. A 59-year-old man with skin and pulmonary lesions after chemotherapy for leukemia [corrected]. N Engl J Med. 2009;361:287-296. 
106. Peltroche-Llacsahuanga H, Manegold E, Kroll G, Haase G. Case report. Pathohistological findings in a clinical case of disseminated infection with Fusarium oxysporum. Mycoses. 2000;43:367-372.

107. Pereiro M Jr, Abalde MT, Zulaica A, Caeiro JL, Florez A, Peteiro C, Toribio J. Chronic infection due to Fusarium oxysporum mimicking lupus vulgaris: case report and review of cutaneous involvement in fusariosis. Acta Derm Venereol. 2001;81:51-53.

108. Perez-Perez L, Pereiro M Jr, Sanchez-Aguilar D, Toribio J. Ulcerous lesions disclosing cutaneous infection with Fusarium solani. Acta Derm Venereol. 2007;87:422-424.

109. Perfect JR. Treatment of non-Aspergillus moulds in immunocompromised patients, with amphotericin B lipid complex. Clin Infect Dis. 2005;40:401-408

110. Pflugfelder SC, Flynn HW Jr, Zwickey TA, Forster RK, Tsiligianni A, Culbertson WW, Mandelbaum S. Exogenous fungal endophthalmitis. Ophthalmology. 1988;95:19-30.

111. Raad II, Hachem RY, Herbrecht R, Graybill JR, Hare R, Corcoran G, Kontoyiannis DP. Posaconazole as salvage treatment for invasive fusariosis in patients with underlying hematologic malignancy and other conditions. Clin Infect Dis. 2006;42:1398-1403.

112. Rezai KA, Eliott D, Plous O, Vazquez JA, Abrams GW. Disseminated Fusarium infection presenting as bilateral endogenous endophthalmitis in a patient with acute myeloid leukemia. Arch Ophthalmol. 2005;123:702-703.

113. Rieger KE, Ridky TW, Sundram UN. Skin nodules in a patient with acute myeloid leukemia and neurological deterioration - quiz case. Disseminated fusariosis. Arch Dermatol. 2010;146:1037-1042.

114. Rippon JW, Larson RA, Rosenthal DM, Clayman J. Disseminated cutaneous and peritoneal hyalohyphomycosis caused by Fusarium species: three cases and review of the literature. Mycopathologia. 1988;101:105-111.

115. Rodriguez-Villalobos H, Georgala A, Beguin H, Heymans C, Pye G, Crokaert F, Aoun M. Disseminated infection due to Cylindrocarpon (Fusarium) lichenicola in a neutropenic patient with acute leukaemia: report of a case and review of the literature. Eur J Clin Microbiol Infect Dis. 2003;22:62-65.

116. Rodriguez CA, Lujan-Zilbermann J, Woodard P, Andreansky M, Adderson EE. Successful treatment of disseminated fusariosis. Bone Marrow Transplant. 2003;31:411-412.

117. Romano C, Caposciutti P, Ghilardi A, Miracco C, Fimiani M. A case of primary localized cutaneous infection due to Fusarium oxysporum. Mycopathologia. 2010;170:39-46.

118. Rothe A, Seibold M, Hoppe T, Seifert H, Engert A, Caspar C, Karthaus M, Fatkenheuer G, Bethe U, Tintelnot K, Cornely OA. Combination therapy of disseminated Fusarium oxysporum infection with terbinafine and amphotericin B. Ann Hematol. 2004;83:394-397.

119. Ruiz N, Fernandez-Martos C, Romero I, Pla A, Maiquez J, Calatrava A, Guillem V. Invasive fungal infection and nasal septum perforation with bevacizumab-based therapy in advanced colon cancer. J Clin Oncol. $2007 ; 25: 3376-3377$

120. Sagnelli C, Fumagalli L, Prigitano A, Baccari P, Magnani P, Lazzarin A. Successful voriconazole therapy of disseminated Fusarium verticillioides infection in an immunocompromised patient receiving chemotherapy. J Antimicrob Chemother. 2006;57:796-798.

121. Sampathkumar P, Paya CV. Fusarium infection after solid-organ transplantation. Clin Infect Dis. 2001;32:1237-1240.

122. Sander A, Beyer U, Amberg R. Systemic Fusarium oxysporum infection in an immunocompetent patient with an adult respiratory distress syndrome (ARDS) and extracorporal membrane oxygenation (ECMO). Mycoses. 1998;41:109-111.

123. Saw SM, Ooi PL, Tan DT, Khor WB, Fong CW, Lim J, Cajucom-Uy HY, Heng D, Chew SK, Aung T, Tan AL, Chan CL, Ting S, Tambyah PA, Wong TY. Risk factors for contact lens-related fusarium keratitis: a case-control study in Singapore. Arch Ophthalmol. 2007;125: 611-617.

124. Selleslag D. A case of fusariosis in an immunocompromised patient successfully treated with liposomal amphotericin B. Acta Biomed. 2006;77:32-35.

125. Sierra-Hoffman M, Paltiyevich-Gibson S, Carpenter JL, Hurley DL. Fusarium osteomyelitis: case report and review of the literature. Scand $J$ Infect Dis. 2005;37:237-240

126. Stanzani M, Vianelli N, Bandini G, Paolini S, Arpinati M, Bonifazi F, Giannini B, Agostinelli C, Baccarani M, Ricci P. Successful treatment of disseminated fusariosis after allogeneic hematopoietic stem cell transplantation with the combination of voriconazole and liposomal amphotericin B. J Infect. 2006;53:243-246.

127. Sturm AW, Grave W, Kwee WS. Disseminated Fusarium oxysporum infection in patient with heatstroke. Lancet. 1989;1:968.

128. Taj-Aldeen SJ, Gene J, Al Bozom I, Buzina W, Cano JF, Guarro J. Gangrenous necrosis of the diabetic foot caused by Fusarium acutatum. Med Mycol. 2006;44:547-552.

129. Terada M, Fujita J, Watanabe S, Kawasaki M, Tanabe H, Anzawa K Mochizuki T. Olecranon bursa with Fusarium solani infection in an otherwise healthy patient. Mycoses. 2011;54:853-855.

130. Testerman GM, Steagald MK, Colquitt LA, Maki A. Disseminated Fusarium infection in a multiple trauma patient. South Med J. 2008;101:320-323

131. Tezcan G, Ozhak-Baysan B, Alastruey-Izquierdo A, Ogunc D, Ongut G, Yildiran ST, Hazar V, Cuenca-Estrella M, Rodriguez-Tudela JL. Disseminated fusariosis caused by Fusarium verticillioides in an acute lymphoblastic leukemia patient after allogeneic hematopoietic stem cell transplantation. J Clin Microbiol. 2009;47:278-281.

132. Tomimori-Yamashita J, Ogawa MM, Hirata SH, Fischman O, Michalany NS, Yamashita HK, Alchorne M. Mycetoma caused by Fusarium solani with osteolytic lesions on the hand: case report. Mycopathologia. 2002;153:11-14.

133. Vagace JM, Sanz-Rodriguez C, Casado MS, Alonso N, GarciaDominguez M, de la Llana FG, Zarallo L, Fajardo M, Bajo R. Resolution of disseminated fusariosis in a child with acute leukemia treated with combined antifungal therapy: a case report. BMC Infect Dis. 2007;7:40

134. Vazquez JA, Singh S, Eliott D, Puklin J, Ben-Joseph AM, Abrams GW Rapid molecular diagnosis of a disseminated fungal infection presenting as sudden bilateral visual loss in a patient with acute myeloid leukemia. Clin Adv Hematol Oncol. 2006;4:914-916.

135. Vincent AL, Cabrero JE, Greene JN, Sandin RL. Successful voriconazole therapy of disseminated Fusarium solani in the brain of a neutropenic cancer patient. Cancer Control. 2003;10:414-419.

136. Viviani MA, Cofrancesco E, Boschetti C, Tortorano AM, Cortellaro M Eradication of Fusarium infection in a leukopenic patient treated with liposomal amphotericin B. Mycoses. 1991;34:255-256.

137. White PL, Perry MD, Barnes RA. An update on the molecular diagnosis of invasive fungal disease. FEMS Microbiol Lett. 2009;296:1-10.

138. Yera H, Bougnoux ME, Jeanrot C, Baixench MT, De Pinieux G, Dupouy-Camet J. Mycetoma of the foot caused by Fusarium solani: identification of the etiologic agent by DNA sequencing. J Clin Microbiol. 2003;41:1805-1808.

139. Yun SJ, Shin MG, Choi C, Kim HJ, Lee JB, Kim SJ, Lee SC, Won YH Fatal disseminated angioinvasive Fusarium falciforme infection in a patient with acute myeloid leukaemia. Br J Dermatol. 2007; 157:407-409.

140. Zhang CZ, Fung MA, Eisen DB. Disseminated fusariosis presenting as panniculitis-like lesions on the legs of a neutropenic girl with acute lymphoblastic leukemia. Dermatol Online J. 2009;15:5. 